National Assessment of Oil and Gas

\title{
Assessment of Undiscovered Carboniferous Coal-Bed Gas Resources of the Appalachian Basin and Black Warrior Basin Provinces, 2002
}

\section{Introduction}

Almost all coal beds contain gases within internal pore spaces and fractures. These gases, which consist mostly of methane, are generally hazardous to mining operations and may form explosive mixtures with oxygen where they are not properly vented from underground coal mining operations. In places, the gas is so abundant that it constitutes an economic resource and is produced from wells. Wells are drilled into unmined coal, which is then fractured artificially in order to release the gas to the well bore in relatively large quantities. Alternatively, wells drain mine gases from the broken down rock (gob) associated with underground coal mining.

\section{Coalbed Methane}

Coalbed methane (CBM) occurs in coal beds of Mississippian and Pennsylvanian (Carboniferous) age in the Appalachian basin, which extends almost continuously from New York to Alabama. In general, the basin includes three structural subbasins: the Dunkard basin in Pennsylvania, Ohio, and northern West Virginia; the Pocahontas basin in southern West Virginia, eastern Kentucky, and southwestern Virginia; and the Black Warrior basin in Alabama and Mississippi (fig. 1). For assessment purposes, the Appalachian basin was divided into two assessment provinces: the Appalachian Basin Province from New York to Alabama, and the Black Warrior Basin Province in Alabama and Mississippi (fig. 1, table 1). By far, most of the coalbed methane produced in the entire Appalachian basin has come from the Black Warrior Basin Province.

Methane degasification in advance of underground mining began in the early 1970s in the Black Warrior Basin Province, and in the late 1970s and early 1980s in the Pocahontas Basin Assessment Unit (AU) of the Appalachian Basin Province in an effort to improve mine safety conditions in deeply buried coal beds. At first, vertical ventilation holes were drilled into the Blue Creek coal bed in Alabama and Pocahontas No. 3 coal bed in Virginia, and the gas that was produced from coal beds in advance of mining, or from gob wells drilled into old works after mining, was vented into the atmosphere. Upon recognition of the value of the resource and resolution of ownership issues, production of CBM commenced in Alabama in 1980 and in Virginia in 1988. Coalbed methane production from the Pocahontas No. 3 coal bed began in southern West Virginia in 1995.

By 2002, annual production of CBM in the Black Warrior Basin Province of Alabama had increased to more than 110 billion cubic feet (Bcf) of gas from 3,357 wells. In the Appalachian Basin

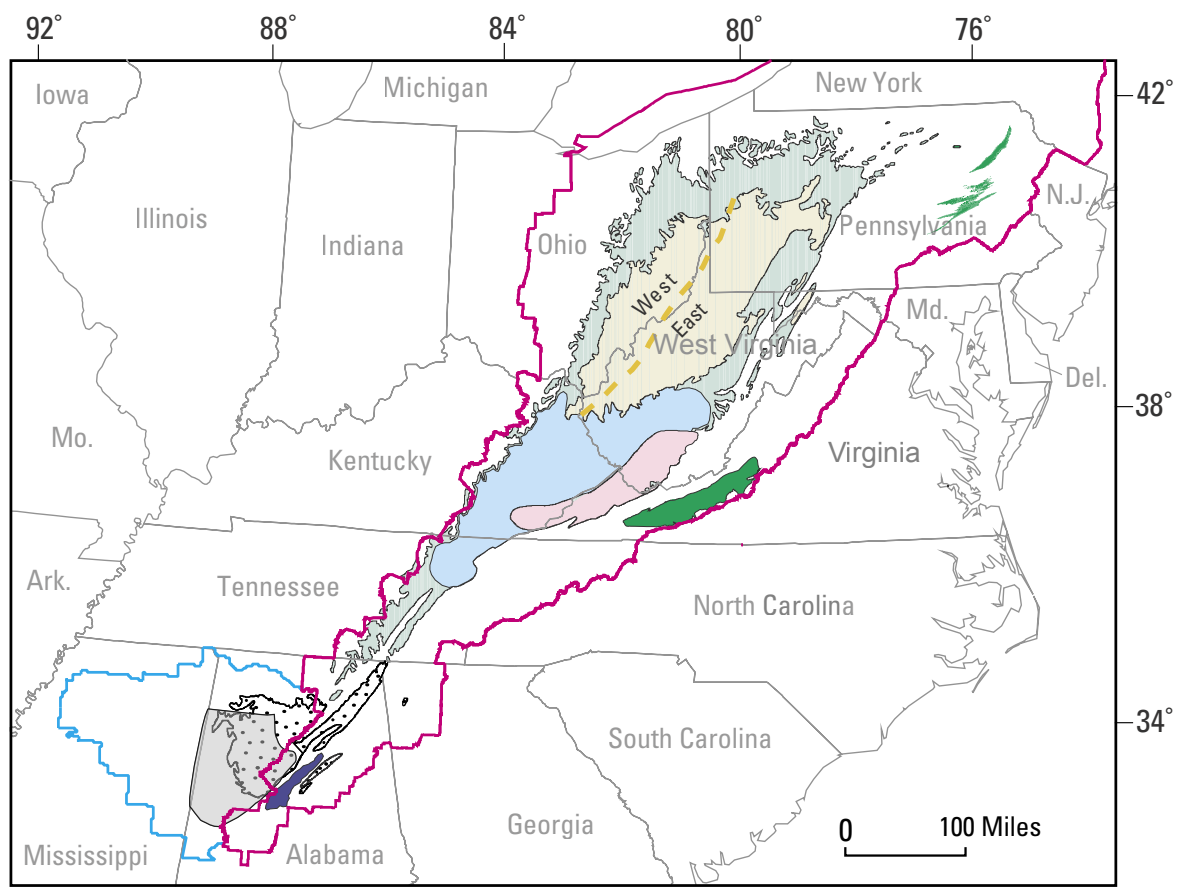

EXPLANATION
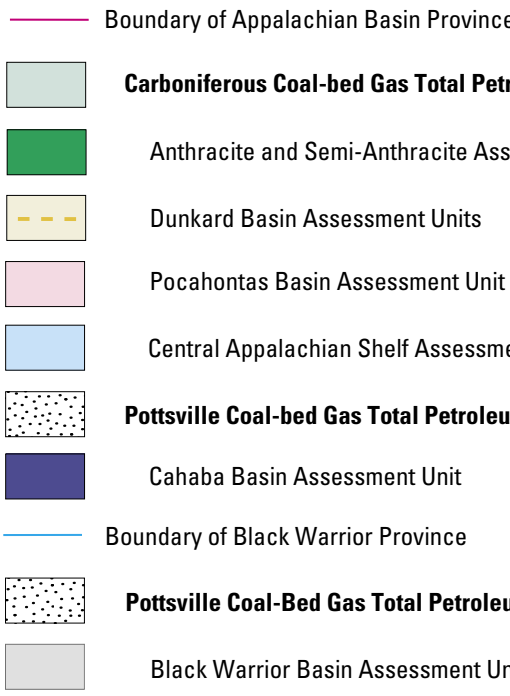

Carboniferous Coal-bed Gas Total Petroleum System

Anthracite and Semi-Anthracite Assessment Unit

Dunkard Basin Assessment Units

Pocahontas Basin Assessment Unit

Central Appalachian Shelf Assessment Unit

Pottsville Coal-bed Gas Total Petroleum System

Cahaba Basin Assessment Unit

Boundary of Black Warrior Province

Pottsville Coal-Bed Gas Total Petroleum System

Black Warrior Basin Assessment Unit

Figure 1. Appalachian basin coalbed methane. Although the Appalachian Basin Province extends northward into New York, no coal-bearing units are found north of Pennsylvania. 
Table 1. Total undiscovered coalbed methane resources of the Appalachian Basin and Black Warrior Basin Provinces.

[BCFG, bi

Fractiles are additive under the

assumption of perfect positive correlation.]

\begin{tabular}{|c|c|c|c|c|c|c|}
\hline \multirow[t]{2}{*}{ Assessment Province } & \multirow[t]{2}{*}{ Total Petroleum System } & \multirow[t]{2}{*}{ Assessment Unit } & \multicolumn{4}{|c|}{ Total Undiscovered Resources of Gas (BCFG) } \\
\hline & & & F95 & F50 & F5 & Mean \\
\hline Appalachian Basin & Carboniferous Coal-bed Gas & Pocahontas Basin & $2,929.57$ & $3,552.81$ & $4,308.64$ & $3,577.32$ \\
\hline Appalachian Basin & Carboniferous Coal-bed Gas & East Dunkard (Folded) & $2,748.71$ & $4,593.61$ & $7,676.78$ & $4,823.03$ \\
\hline \multirow[t]{2}{*}{ Black Warrior Basin } & Pottsville Coal-bed Gas & Black Warrior & $4,614.56$ & $6,854.42$ & $10,181.47$ & $7,055.63$ \\
\hline & & Total Assessed Coal-Bed Gas Resources & $10,292.84$ & $15,000.84$ & $22,166.89$ & $15,455.98$ \\
\hline Appalachian Basin & Carboniferous Coal-bed Gas & West Dunkard (Unfolded) & \multicolumn{4}{|c|}{ Not Quantitatively Assessed } \\
\hline Appalachian Basin & Carboniferous Coal-bed Gas & Central Appalachian Shelf & \multicolumn{4}{|c|}{ Not Quantitatively Assessed } \\
\hline Appalachian Basin & Carboniferous Coal-bed Gas & Appalachian Anthracite and Semi-Anthracite & \multicolumn{4}{|c|}{ Not Quantitatively Assessed } \\
\hline Appalachian Basin & Pottsville Coal-bed Gas & Cahaba Basin & \multicolumn{4}{|c|}{ Not Quantitatively Assessed } \\
\hline
\end{tabular}

Province, 2,359 wells in the Pocahontas Basin AU in Virginia and southern West Virginia produced 65.8 Bcf; and 252 wells in the East Dunkard (Folded) AU in Pennsylvania and northern West Virginia produced 1.4 Bcf of CBM. As of 2003, cumulative production from the Black Warrior Basin Province was about 1.5 trillion cubic feet (Tcf) of CBM, and cumulative production from the Pocahontas Basin and East Dunkard (Folded) Basin AUs was about $439 \mathrm{Bcf}$ and $8.5 \mathrm{Bcf}$, respectively. Although the gas is chiefly methane, small amounts of other gases may be present. Gob gas produced from previously mined areas (coal mine methane) commonly contains relatively large amounts of nitrogen, oxygen, and carbon dioxide.

\section{Assessment Results}

The results of the U.S. Geological Survey's 2002 assessment of the Appalachian Basin and Black Warrior Basin Provinces for coalbed methane are shown in table 1 . These two provinces were subdivided into assessment units and only the units that were currently productive were assessed. The assessment was conducted with the assumption that the bulk of the exploration and discoveries in the next 30 years would be within the Black Warrior basin, Pocahontas basin, and the East Dunkard (Folded) Assessment Units.

Approximately $15.5 \mathrm{Tcf}$ of technically recoverable undiscovered methane resources were assessed at the statistical mean in the Appalachian Basin and Black Warrior Provinces overall. Assessment units in the Appalachian Basin with no commercial development or with little reliable data at the time of the assessment were not assessed quantitatively. These areas, however, are recognized as having considerable potential for future development because of the wide distribution of coal and the occurrences of marginally economic amounts of gas within them.

\section{Selected References}

Hatch, J.R., Pawlewicz, M.J., Charpentier, R.R., Cook, T.A., Crovelli, R.A., Klett, T.R., Pollastro, R.M., and Schenk, C.J., 2003, Assessment of undiscovered oil and gas resources of the Black Warrior Basin Province, 2002: U.S. Geological Survey Fact Sheet FS-038-03, 2 p.

Markowski, A.K., 1998, Coalbed methane resource potential and current prospects in Pennsylvania: International Journal of Coal Geology, v. 38, p. $137-159$.
Milici, R.C., 2004, Assessment of Appalachian Basin Oil and Gas Resources; Carboniferous coal-bed gas total petroleum system: U.S. Geological Survey Open-File Report 2004-1272, available only online at http://pubs.usgs.gov/of/2004/1272. (Accessed August 17, 2004). [This publication provides the geologic data and references supporting the assessment.]

Milici, R.C., Ryder, R.T., Swezey, C.S., Charpentier, R.R., Cook, T.A., Crovelli, R.A., Klett, T.R., Pollastro, R.M., and Schenk, C.J., 2003, Assessment of undiscovered oil and gas resources of the Appalachian Basin Province, 2002: U.S. Geological Survey Fact Sheet FS-009-03.

Nolde, J.E., and Spears, David, 1998, A preliminary assessment of in place coalbed methane resources in the Virginia portion of the central Appalachian Basin: International Journal of Coal Geology, v. 38, p. 115-136.

Pashin, J.C., and Hinkle, Frank, 1997, Coalbed methane in Alabama: Geological Survey of Alabama Circular 192, $71 \mathrm{p}$.

Rice, D.D., and Finn, T.M., 1996, Geologic framework and description of coalbed gas plays, in Gautier, D.L., Dolton, G.L., Takahashi, K.I., and Varnes, K.L., eds., 1995 National assessment of United States oil and gas resources; results, methodology, and supporting data: U.S. Geological Survey Digital Data Series 30, 1 CD-ROM.

West Virginia Geological and Economic Survey, 2004, Coal-bed methane (CBM) wells: Morgantown, W. Va., West Virginia Geological and Economic Survey Web site at http://www.wvgs.wvnet.edu/www/datastat/ datastat.htm. (Accessed August 16, 2004)

By Robert C. Milici and Joseph R. Hatch

\section{For Further Information}

CBM Resources of the Appalachian Basin Province:

Robert C. Milici

U.S. Geological Survey

956 National Center

Reston, VA 20192

Telephone: 703-648-6541,E-mail: rmilici@usgs.gov

CBM Resources of the Black Warrior Basin Province:

Joseph R. Hatch

U.S. Geological Survey

Denver Federal Center, MS 977, P.O. Box 25046

Denver, CO 80225

Telephone: 303-235-5418, E-mail: jrhatch@usgs.gov 